NASZA DERMATOLOGIA Onlin OUR DERMATOLOGY Online

Source of Support:

Nil

Competing Interests:

None

\section{EPONYMS IN DERMATOLOGY LITERATURE LINKED TO CANADA}

\author{
Khalid Al Aboud ${ }^{1}$, Ahmad Al Aboud ${ }^{2}$ \\ ${ }^{1}$ Dermatology Department, King Faisal Hospital, Makkah, Saudi Arabia \\ ${ }^{2}$ Dermatology Department, King Abdullah Medical City, Makkah, Saudi Arabia
}

Corresponding author: Dr. Khalid Al Aboud

amoa65@hotmail.com
Canada is a North American country with a population of approximately 33.4 million as of 2011. Per capita income is the world's ninth highest, and Canada ranks sixth globally in human development [1].

There are several eponyms in dermatology which are linked to Canada. In Table I [2-11], we listed selected eponyms in dermatology literature which are linked to Canada.

Numerous activities related to dermatology have occurred in Canada. The Canadian Dermatology Association, which published the well-known periodical, The Journal of Cutaneous Medicine and Surgery, was founded in 1925. The Canadian Dermatology Foundation was established in 1969 and The Canadian Dermatology Nurses Association was founded on 1997.

As a testimony of its Excellency in dermatology teaching, there are several specialized fellowships in Canada, in different subspecialties of dermatology. These fellowships accept candidates from all over the world.

There are also important educational resources in dermatology which are based in Canada. Just an example is, Dermanities (www.dermanities.com), which was launched in 2002 by Benjamin Barankin and David J. Elpern.

The city of Vancouver, in Canada will host the 23rd World Congress of Dermatology in 2015.

\begin{tabular}{|c|c|}
\hline $\begin{array}{l}\text { Eponyms in dermatology } \\
\text { literature linked to Canada }\end{array}$ & Remarks \\
\hline $\begin{array}{c}\text { Birt-Hogg-Dube' syndrome } \\
{[2-4]}\end{array}$ & $\begin{array}{l}\text { It is an autosomal dominant trait characterized by multiple fibrofolliculomas and } \\
\text { extracutaneous cancer proneness. It is named after three Canadian doctors, Arthur } \\
\text { Robert Birt (dermatologist) (Fig. 1), Georgina Hogg (pathologist), (Fig. 2), and Jim } \\
\text { Dube' (endocrinologist). } \\
\text { Between } 1964 \text { and 1972, Arthur Robert Birt was professor and head of the department } \\
\text { of dermatology at the University of Manitoba, where he proved a popular and effective } \\
\text { teacher. In recognition of Dr. Birt's achievements, the University of Manitoba made } \\
\text { him emeritus professor of medicine (dermatology) in1977. } \\
\text { Birt-Hogg-Dube' syndrome, is actually first reported in 1975, by a German } \\
\text { dermatologist, Otto Paul Hornstein and his coworker, Monika Knickenberg and some- } \\
\text { times called Hornstein-Knickenberg-Syndrom. That is why a recent paper suggested } \\
\text { that the term ,"Hornstein-Birt-Hogg-Dubé syndrome" appears to be appropriate. Otto } \\
\text { Paul Hornstein was born } 1926 \text { in Munich. He was the former director of the Department } \\
\text { of Dermatology, University of Erlangen-Nuremberg. }\end{array}$ \\
\hline Cullen's sign $[5,6]$ & $\begin{array}{l}\text { Cullen's sign is described as superficial edema with bruising in the subcutaneous fatty } \\
\text { tissue around the peri-umbilical region. It is also known as peri-umbilical ecchymosis. } \\
\text { The sign was named after Thomas S. Cullen (1868-1953), (Fig. 3), a Canadian } \\
\text { Gynecologist who researched gynecological disease including uterine cancer and } \\
\text { ectopic pregnancy, and became a Professor at John Hopkins Hospital. He first described } \\
\text { the sign in } 1918 \text { after a case of a ruptured extra uterine pregnancy. }\end{array}$ \\
\hline
\end{tabular}

Table I. Selected Eponyms in dermatology literature linked to Canada 


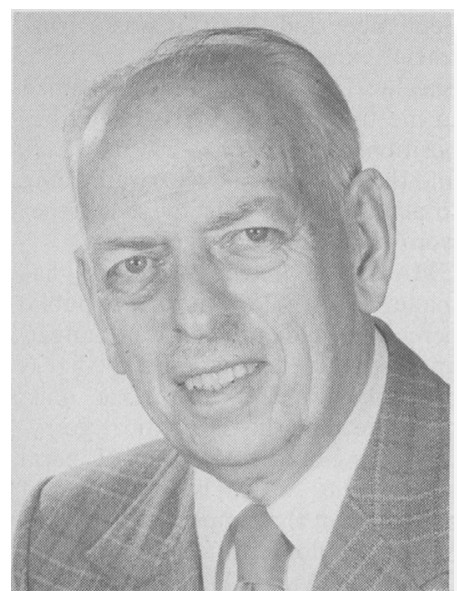

Figure 1. Arthur Robert Birt.

Reproduced from Reference 3.

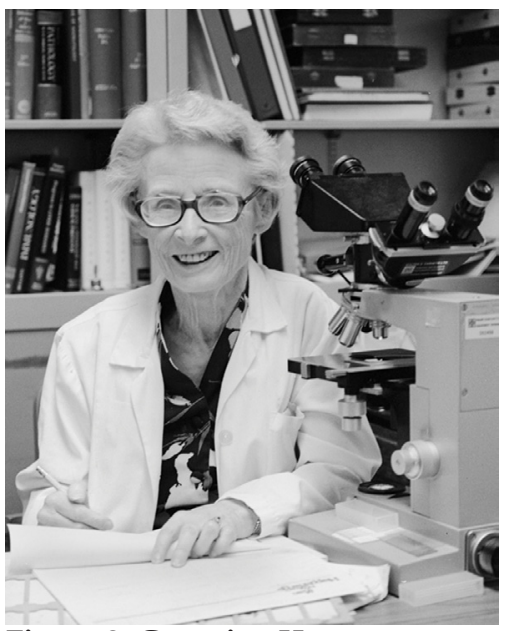

Figure 2. Georgina Hogg.

A curtesy of „Dr David

Rayner,Walter Mackenzie Health

Sciences Centre, Edmonton,

Alberta, Canada"

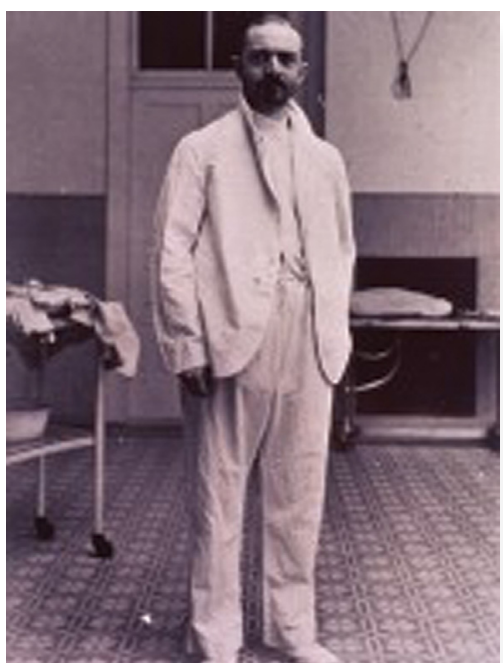

Figure 3. Thomas Stephen Cullen (1868-1953). A courtesy of National Library of Medicine

\begin{tabular}{|c|c|}
\hline $\begin{array}{l}\text { Eponyms in dermatology } \\
\text { literature linked to Canada }\end{array}$ & Remarks \\
\hline Hunter syndrome [7] & $\begin{array}{l}\text { Hunter syndrome, also known as mucopolysaccharidosis (MPS) II, is one of at least } 10 \\
\text { defined mucopolysaccharidoses. It is named after, Charles A. Hunter (1873-1955), a } \\
\text { Scottish-Canadian physician. } \\
\text { Dr. Charles Hunter, in Manitoba, Canada, first described Hunter syndrome in } 1917 \\
\text { when he documented short stature, unusual facial features, hepatomegaly, deafness, } \\
\text { heart disease, and nodular skin lesions in two brothers. Cutaneous features of this } \\
\text { syndrome are firm, hypopigmented to skin-colored papules and nodules generally } \\
\text { found on the back, particularly near the scapulae, as well as on the chest, neck, arms, or } \\
\text { thighs. These occur generally before } 10 \text { years of age in both the mild and severe forms } \\
\text { of Hunter syndrome. }\end{array}$ \\
\hline $\begin{array}{c}\text { Masson's neuronevus } \\
\text { and } \\
\text { Masson's pseudoangiosarcoma } \\
{[8]}\end{array}$ & $\begin{array}{l}\text { Masson's neuronevus was used to refer to the neurotized nevus. Masson's } \\
\text { pseudoangiosarcoma or the Masson lesion are the other names for intravascular } \\
\text { papillary endothelial hyperplasia. } \\
\text { These were named after Claude L. Pierre Masson (1880-1959), (Fig. 4), French-born } \\
\text { Canadian pathologist. } \\
\text { He was the chair of anatomic pathology at the hospital and medical school at } \\
\text { Strasbourg, France. In } 1927 \text {, while he was } 46 \text { years old, Masson resigned his } \\
\text { position at Strasbourg and accepted the position of chief of anatomic } \\
\text { pathology at the University of Montreal Medical School. Pierre Masson died at the age } \\
\text { of } 79 \text { years. He is buried, as he wished, at the cemetery of Notre-Dame-des-Neiges, } \\
\text { atop Mont Royal, where today one has a grand view of the University of Montreal. } \\
\end{array}$ \\
\hline
\end{tabular}

Table I. Selected Eponyms in dermatology literature linked to Canada (continued) 


\begin{tabular}{|c|c|}
\hline $\begin{array}{l}\text { Eponyms in dermatology } \\
\text { literature linked to Canada }\end{array}$ & Remarks \\
\hline \begin{tabular}{c}
\multicolumn{2}{c}{ Osler's nodes } \\
and \\
Osler-Weber-Rendu \\
{$[9]$}
\end{tabular} & $\begin{array}{l}\text { Osler's nodes are painful, red, raised lesions found on the hands and feet. They are } \\
\text { associated with a number of conditions, including infective endocarditis. } \\
\text { Osler-Weber-Rendu syndrome or Osler-Weber-Rendu disease are another names for } \\
\text { Hereditary hemorrhagic telangiectasia which is a familial syndrome characterized by } \\
\text { multiple telangiectasia of the skin, and of the oral, nasal and gastrointestinal mucous } \\
\text { membranes. } \\
\text { The above conditions and some other medical conditions are named after Sir William } \\
\text { Osler. } \\
\text { Osler was a Canadian physician, (1849-1919), (Fig. 5) a native of Canada who at the } \\
\text { age of } 35 \text { came to USA for } 21 \text { years and then moved to the England for the final } 14 \\
\text { years. } \\
\text { Frederick Parkes Weber (1863-1962) was English physician. Henri Jules Louis Marie } \\
\text { Rendu (1844-1902) was a French physician. }\end{array}$ \\
\hline & $\begin{array}{l}\text { Figure 5. William Osler (1849-1919). } \\
\text { A courtesy of National Library of } \\
\text { Medicine }\end{array}$ \\
\hline \multirow[t]{2}{*}{ Senear-Usher syndrome [10] } & $\begin{array}{l}\text { This is eponym for what is also known as pemphigus erythematodes. It is named after } \\
\text { the American dermatologist, Frances Eugene Senear (1889-1958) and the Canadian } \\
\text { dermatologist, Barney David Usher (1899-1978). Usher, (Fig. 6), is the first Canadian } \\
\text { dermatologist to have his name eponymically attached to a disease. He was born and } \\
\text { received his early medical education in Montreal and his MD from McGill University } \\
\text { in 1922. In 1926, in collaboration with Senear, Usher published the classic report on } \\
\text { pemphigus erythematodes. }\end{array}$ \\
\hline & $\begin{array}{l}\text { Figure 6. Barney David Usher (1899-1978). } \\
\text { Reproduced from Reference } 10\end{array}$ \\
\hline
\end{tabular}




\section{REFERENCES}

1. Canada. [A page on the Internet].From Wikipedia, the free encyclopedia Wikipedia ${ }^{\circledR}$ is a registered trademark of the Wikimedia Foundation, Inc. [This page was last modified 2012 Sep 14; cited 2012 Sep 15] .Available at; http://en.wikipedia.org/wiki/ Canada

2. Happle R: Hornstein-Birt-Hogg-Dubé syndrome: a renaming and reconsideration. Am J Med Genet A. 2012;158A:1247-51.

3. Gray C: Arthur birt. Can Med Assoc J. 1983;129:1299.

4. Burgdorf WH: Cancer-associated genodermatoses: a personal history. Exp Dermatol. 2006;15:653-66.

5. Rahbour G, Ullah MR, Yassin N, Thomas GP: Cullen's sign Case report with a review of the literature. Int J Surg Case Rep. 2012;3:143-6
6. Al Aboud K, Al Hawsawi K, Ramesh V, Al Aboud D, Al Githami A: Cutaneous signs. Skinmed. 2003;2:104-7.

7. Lonergan CL, Payne AR, Wilson WG, Patterson JW, English JC 3rd: What syndrome is this? Hunter Syndrome. Pediatr Dermatol. 2004;21:679-81.

8. Steffen C: The man behind the eponym: C. L. Pierre Masson. Am J Dermatopathol. 2003;25:71-6.

9. Caplan RM: Osler's legacies to dermatologists. Int J Dermatol. 1998;37:72-5.

10. Steffen C, Thomas D: The men behind the eponym: Francis E. Senear, Barney Usher, and the Senear-Usher syndrome. Am J Dermatopathol. 2003;25:432-6.

Copyright by Khalid Al Aboud. This is an open access article distributed under the terms of the Creative Commons Attribution License, which permits unrestricted use, distribution, and reproduction in any medium, provided the original author and source are credited.

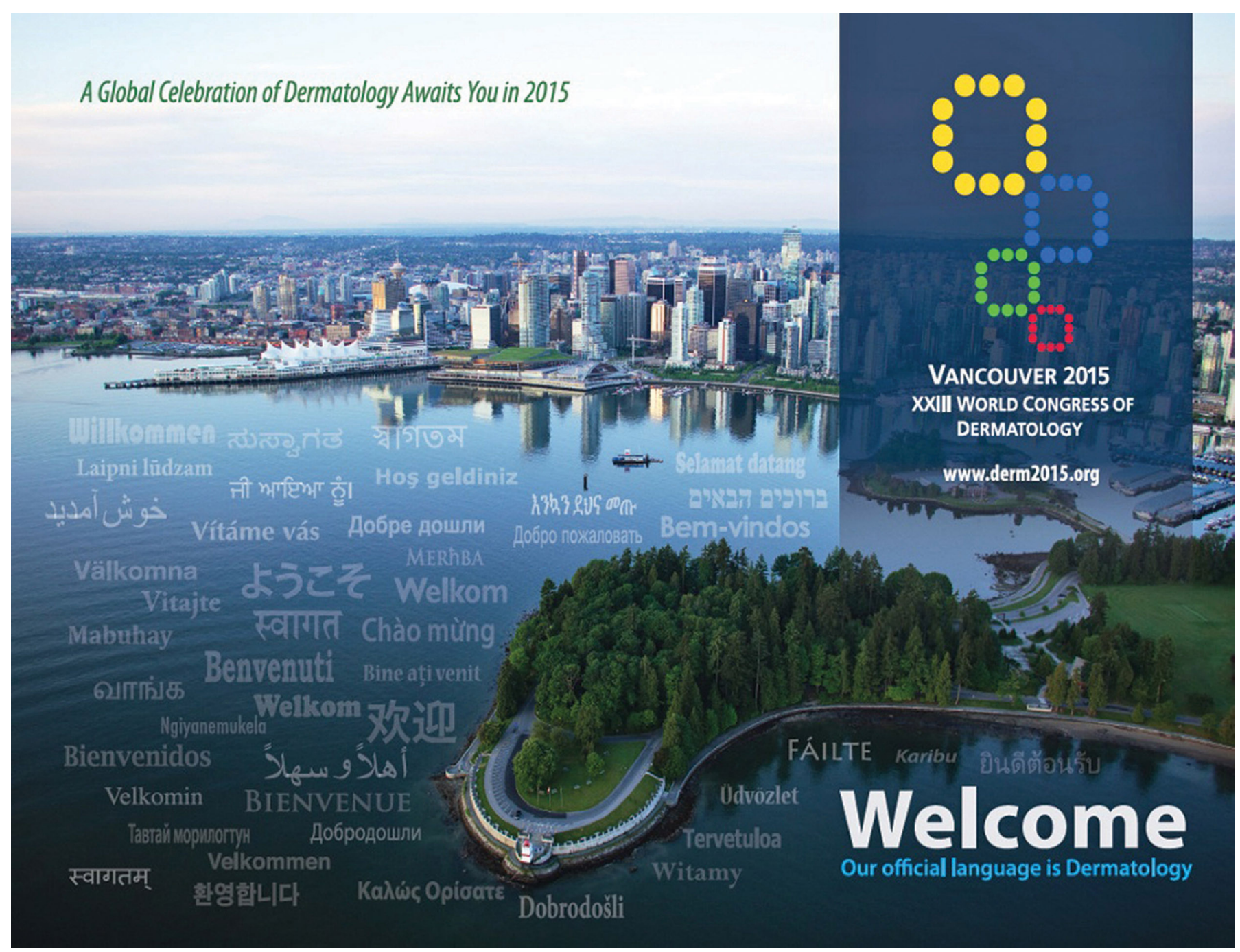

